\title{
Implementation of non-isolated three-port converter through augmented time response
}

\author{
Ramya Devasahayam, Godwin Immanuel D
}

Sathyabama Institute of Science and Technology, India

\begin{tabular}{l}
\hline \hline Article Info \\
\hline Article history: \\
Received Mar 1, 2019 \\
Revised Feb 22, 2021 \\
Accepted Mar 10, 2021 \\
\hline
\end{tabular}

\section{Keywords:}

Coupled inductor

High voltage gain

Pie-filter

PV-panel

Three port converters

\begin{abstract}
The work is concerning a multi-port dc-dc converter with improved time response and steady state output. Here the converter carries bare amount of switches for managing the power with mono inductance. The inductance and along with that the switched capacitance are pre owned to bring large voltage gain. This paper put forwarded an appropriate controller for the closed loop monitored high-gain converter with three ports. Higher is that the conversion rate. This converter is also a good interface between DC-source and load that aims to progressing time response with FLC and PI controller in the closed loop system. The converter with the PI controller and FLC is look over and the fast responses are compared with time domain specifications. The simulation outcome indicates that the FLC based converter brings most excellent time domain response.
\end{abstract}

This is an open access article under the $\underline{C C B Y-S A}$ license.

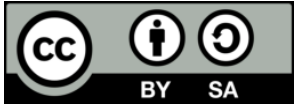

\section{Corresponding Author:}

Ramya Devasahayam

Sathyabama Institute of Science and Technology

Chennai-119, India

Email: ramya.devasahayam@gmail.com

\section{INTRODUCTION}

The use of electricity is increasing day by day. As non-renewable energy sources would run out in few years many research developments are going on renewable energy sources to generate power. PV source is one of primesources of renewable energy [1]-[3]. Therefore, batteries are used for continuous supply of power to load. Figure1 shows a photo voltaic system with three port converter and a battery backup. The limitation of conventional boost converter is that it should activate at tremendous duty cycle ratios to attain required voltage gains which may results in extreme conduction losses, severe reverse recovery losses. Other method of increasing the gain of voltage is by converters with switched capacitor or switched inductor this method is complex when achieving the conversion ratio. Due to high voltage ratings devices undergo more conduction losses in this technique [4], [5].

To boost the voltage gain in an inaccessible dc-dc converter use an inductor which is coupled. The above-mentioned method in boost converters can supply high voltage gain skiping a severe duty cycle operation [6], [7]. Also, efficiency is boosted with soft switching in high power applications. As we need high voltage gain zero voltage switching (ZVS) is used rather than zero current switching (ZCS) as this technique boosts the voltage and decrease the current passing through the device that is discussed in [8]-[10]. Also, in this paper the simulation results of PI and a fuzzy closed loop controller is compared. In the recent years, FLC has good approach of actual mathematical model of the controlled system [11], [12]. The high gain converter enhanced with fuzzy logic controller shows considerable improvement. 


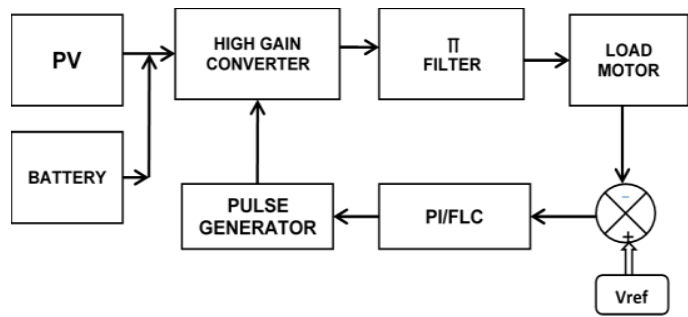

Figure 1. Block diagram of non-isolated three-port converter

\section{PROPOSED THREE PORT CONVERTER}

The proposed converter topology has the power switches, energy storage elements, two capacitors, and a pi filter circuit to filter the ripples as shown in Figure 2. To the bidirectional port circuit [13]-[18] the primary input source is $V_{p v}$ and secondary source is $V_{b t}$

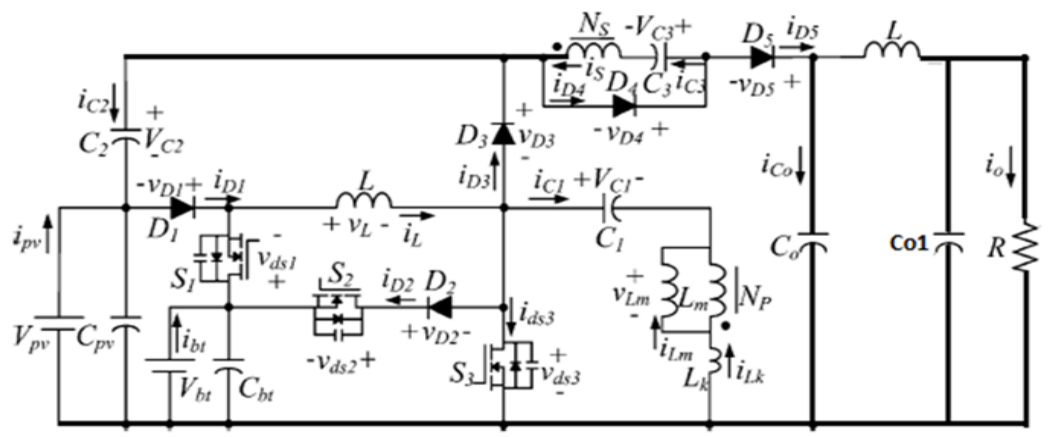

Figure 2. Proposed converter topology

\section{DESIGN PROCEDURE}

The precise value of capacitance and inductance makes a right choice of preferred output. The desired values of energy storage elements inductance and capacitance can be obtained using the following formulae.

Let $\mathrm{X}_{\mathrm{L}}$ be the inductive reactance and $\mathrm{X}_{\mathrm{C}}$ be the capacitive reactance.

$$
\begin{aligned}
& \mathrm{X}_{\mathrm{c}}=1 / 2 \pi \mathrm{fc} \\
& \mathrm{X}_{\mathrm{L}}=2 \pi \mathrm{fl}
\end{aligned}
$$

The design ofoutput filter circuit is expressed as follows, Assume ripple factor $(r)=10^{\wedge}-4$

$$
\mathrm{R}=\sqrt{3} / \mathrm{w}^{2} \mathrm{lc}
$$

The losses can be calculated for the devices

For Mosfet $=\mathrm{v}_{\mathrm{d}} * \mathrm{i}_{\mathrm{d}}$

For Diode $=v_{\mathrm{d}} * \mathrm{i}_{\mathrm{d}}$

Total losses $=$ losses in mosfet + losses in diode.

\section{SIMULATION DIAGRAM FOR THE PROPOSED CONVERTER}

\subsection{Simulink model for proposed converter with $R$ load}

The simulink model for the projected elevated step up three port converters with the resistive load is shown in Figure 3. In this model the power switches, the diodes, the coupled inductor and the pi filter circuits 
are connected. The pulse generator triggers the power mosfets with resistive load. The scope is used to measure the voltage and current across each and every device.

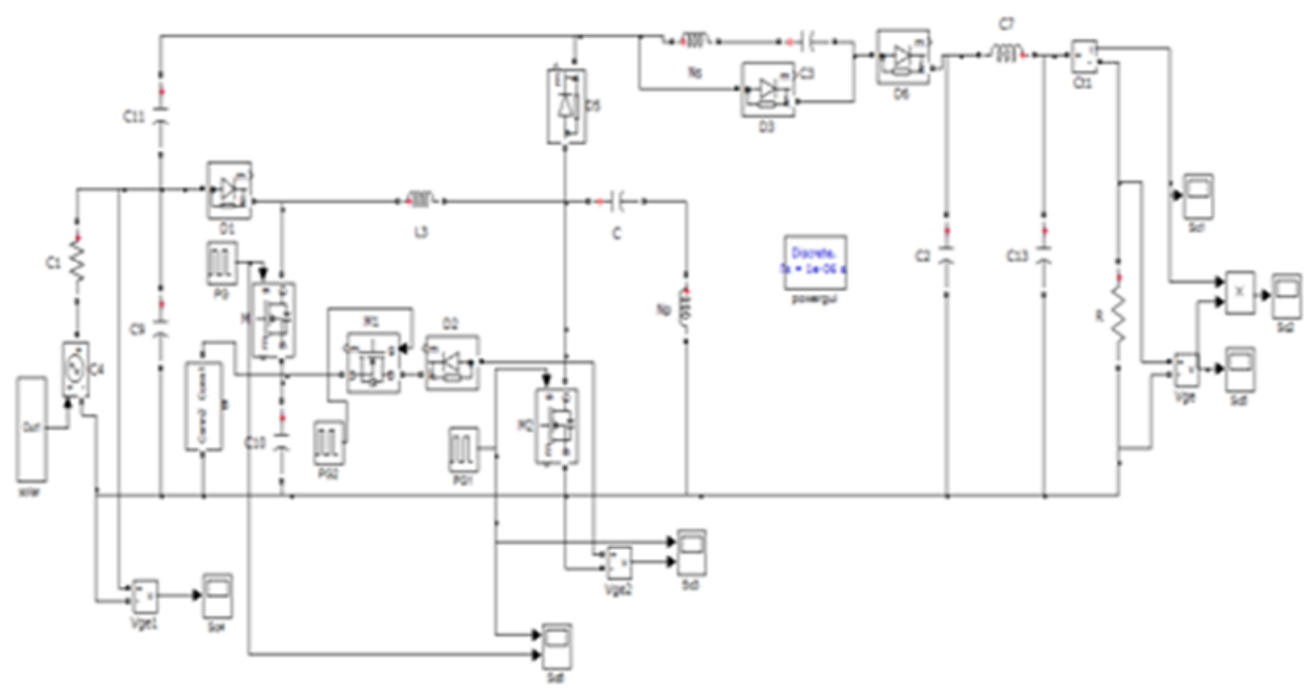

Figure 3. Simulation diagram for proposed high step up converter with R load

The input voltage is taken from the photo volataic source. In the above simulink model for the proposed converter circuit the dc input voltage of $12 \mathrm{~V}$ is given by connecting the photovoltaic module and is shown in Figure 4

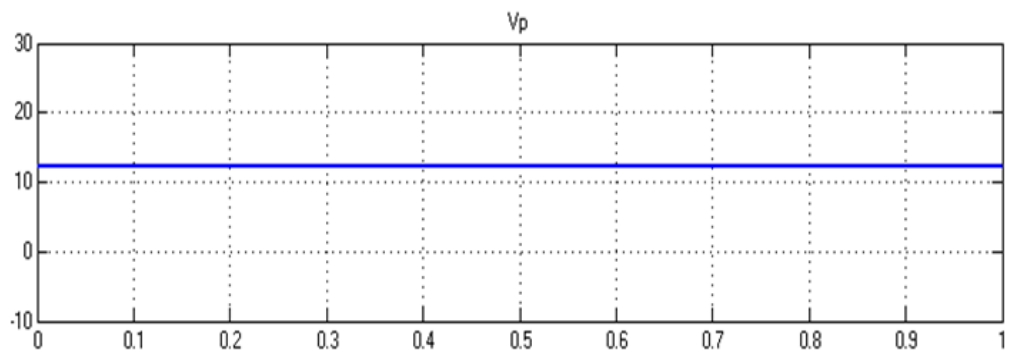

Figure 4. Input voltage

To drive the controller circuit effectively the switching pulses are generated. The switching pulses generated for $\mathrm{Vg} 3$ and $\mathrm{Vg} 1$ of the projected high step up three port converters is shown in Figure 5. The switching pulses and the drain to source voltage across Vg3 and Vds are shown in Figure 6.

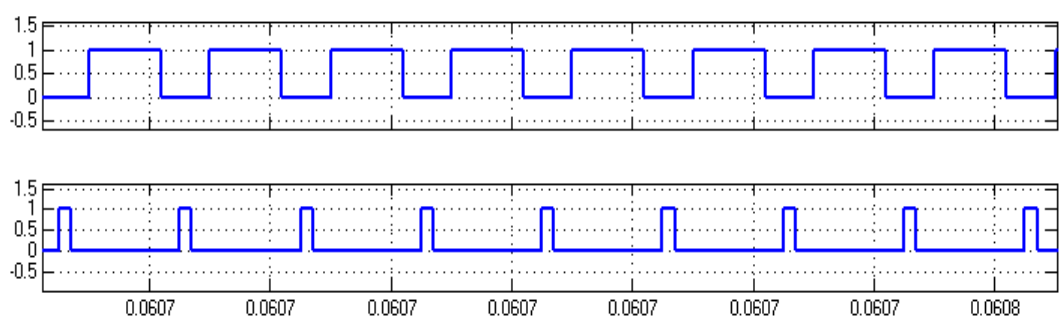

Figure 5. Switching pulse for high step up converter 

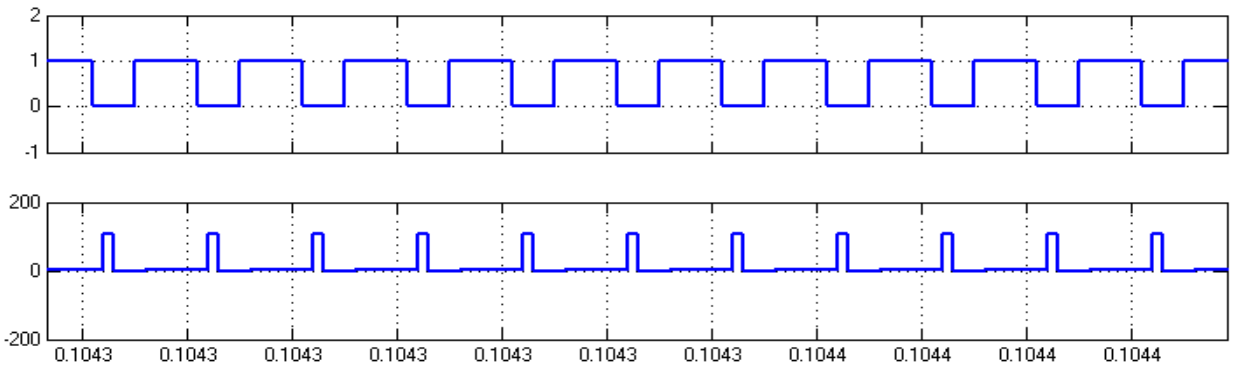

Figure 6. Switching pulse \& drain to source voltage

The simulation output voltage of the converter using simulink is shown above in Figure 7. The main objective is to build a renewable energy-based converter solar photo voltaic system. For the input voltage of $12 \mathrm{~V}$ we can get the output voltage of $105 \mathrm{~V}$.

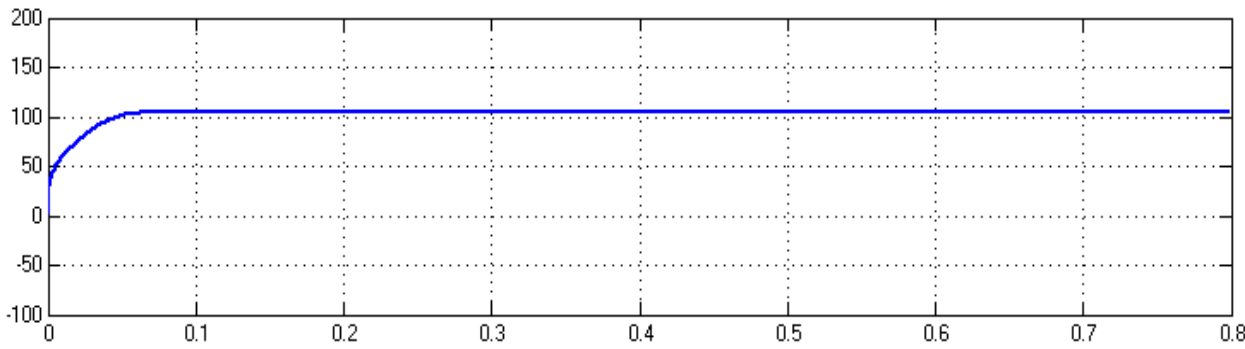

Figure 7. Output voltage

Ripple voltage is the leakage of alternating voltage in DC output voltage. The output ripple voltage generated in the anticipated three port converter circuit with the combination of resistive load is shown in Figure 8.

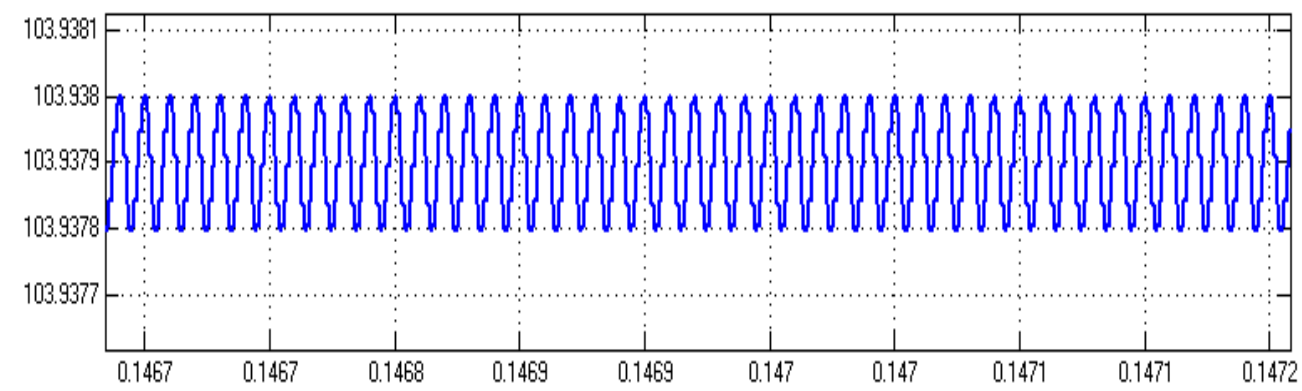

Figure 8. Output ripple voltage

\subsection{Simulink model for proposed converter with motor load}

In the below simulink model the resistive load is replaced by the motor load. Figure 9 shows the simulation diagram of proposed converter circuit connected with the motor load. The scope is connected at the load side to check the speed of the motor in rpm and Torque in $\mathrm{N}-\mathrm{m}$. 


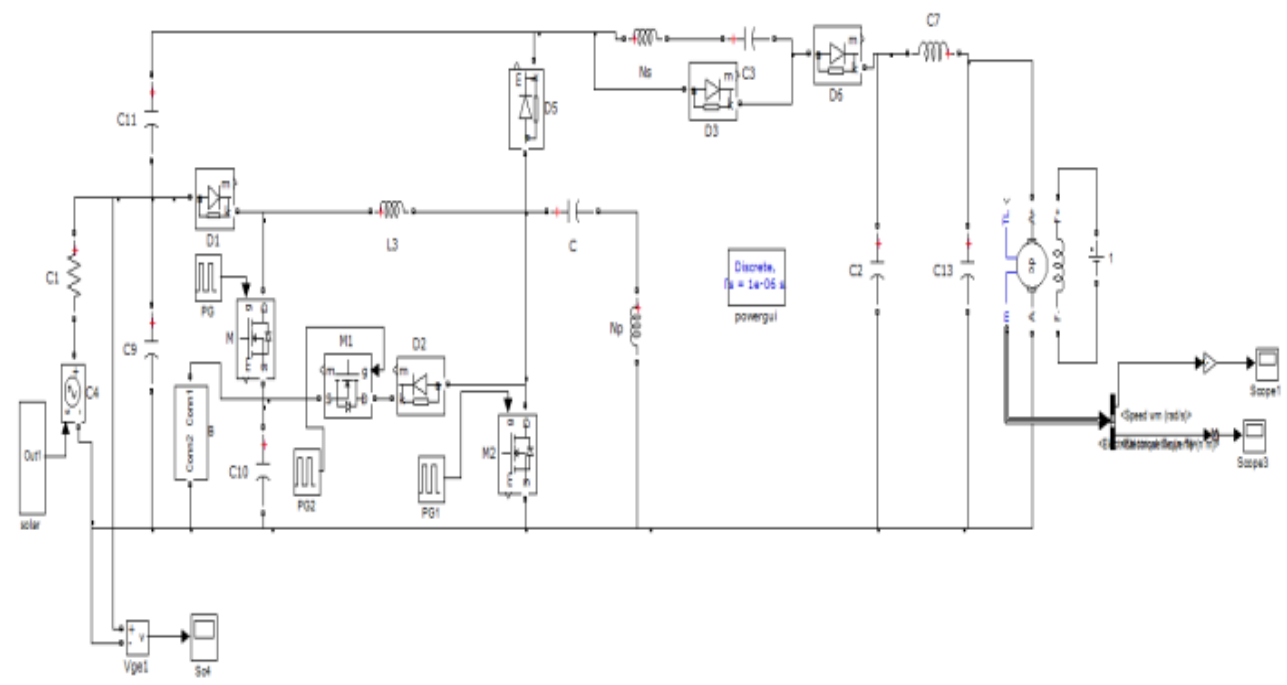

Figure 9. Simulation diagram of converter with motor load

Similarly, when the motor load is allied at output terminal of the converter with an input voltage of $12 \mathrm{~V}$ we can see that motor runs at a speed of $1500 \mathrm{rpm}$ is represented in Figure 10. The speed of the motor is progressively growing for a period of instance subsequent to that it maintains constant speed.

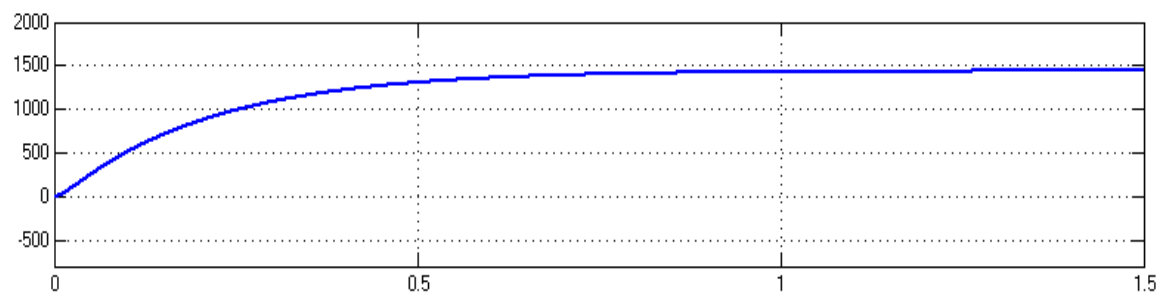

Figure 10. Motor speed in rpm

The preliminary torque developed is soaring very high. The torque developed in the motor rapidly increases to its maximum value and settle down to its steady state value. The torque developed in the motor load is shown in Figure 11.

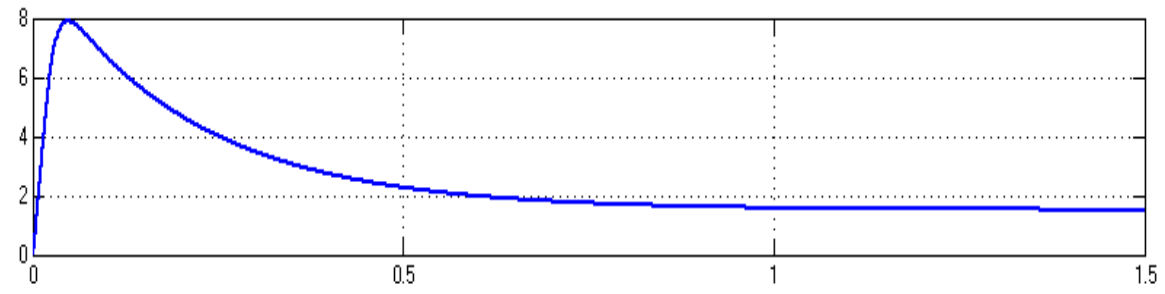

Figure 11. Torque in N-m

\subsection{Simulink model for proposed converter of closed loop system with $\mathbf{R}$ load}

Figure 12 shows the simulation diagram of proposed three port converter of closed loop system using PI controller with resistive load. The input supply of $12 \mathrm{~V}$ and $60 \mathrm{~W}$ boosting converter is used for simulation. The value of $K_{p}=0.018$ and $K_{i}=6$. The Ton and Toff ratio is given to the transfer function model to obtain the output value. 


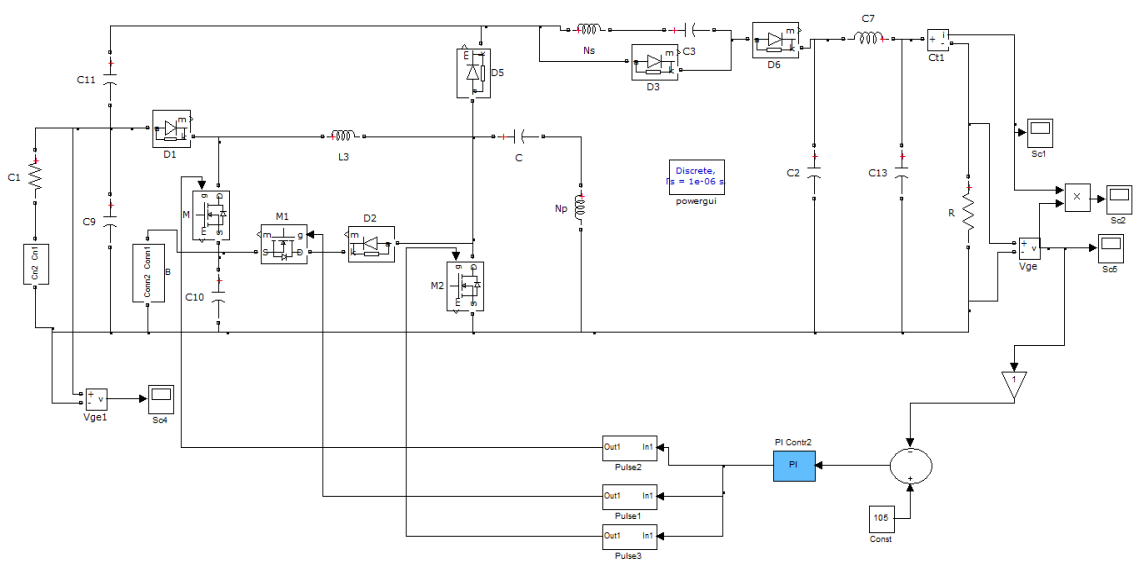

Figure 12. Simualtion diagram of closed loop system with R-load

In PI controller when the disturbance is given at particular instant of time at the input, the time taken to settle that is to come to a constant voltage will be long and is shown in Figure 13. Similarly the output current is shown in Figure 14 and the output power is shown in Figure 15.

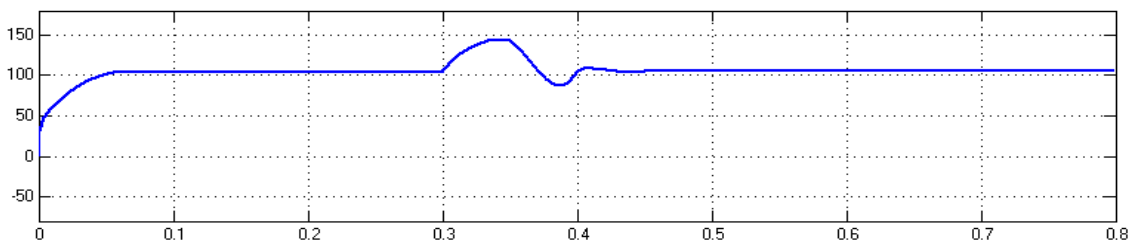

Figure 13. Output voltage

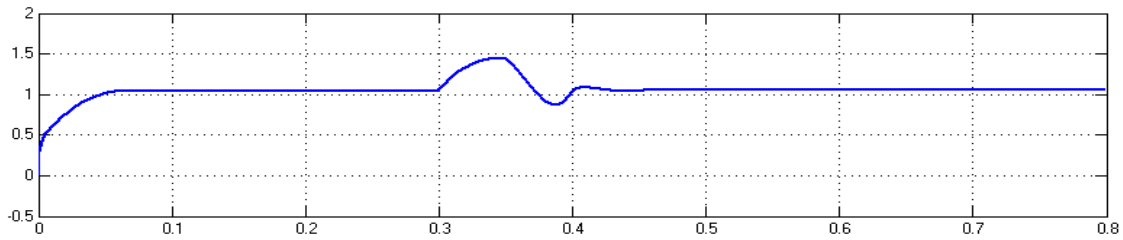

Figure 14. Output current

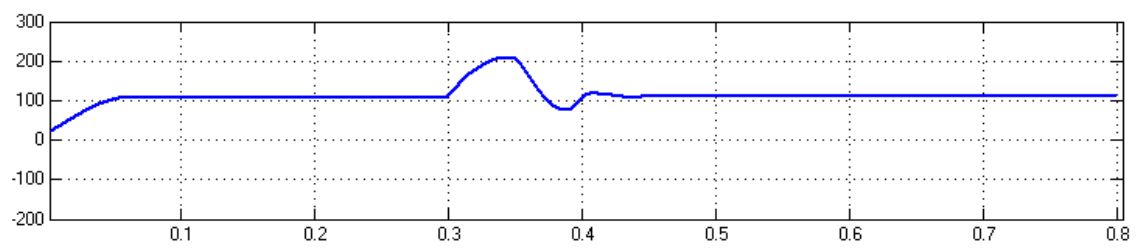

Figure 15. Output power

\subsection{Simulink model for proposed converter of closed loop system with motor load}

Figure 16 shows the simulation diagram of proposed three port converter of closed loop system using PI controller with motor load. The input supply of 12 volts and 60 watts boosting converter is used for 
simulation. The value of $K_{p}=0.018$ and $K_{i}=6$. The Ton and Toff ratio is given to the transfer function model to obtain the output value.

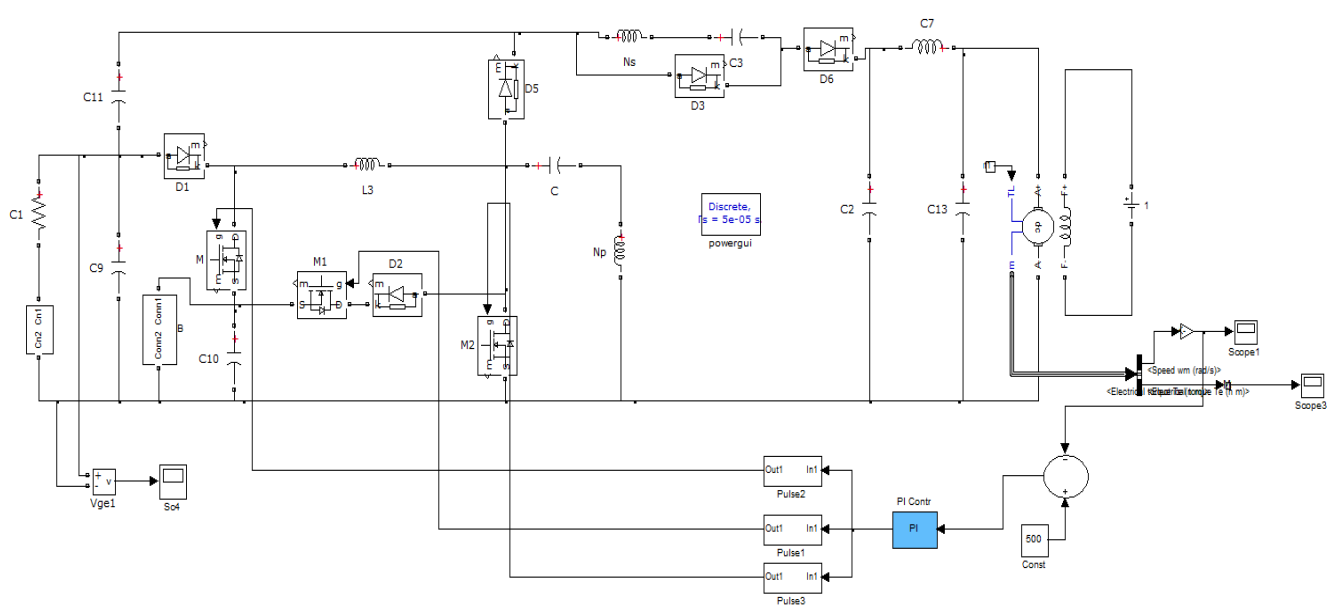

Figure 16. Simualtion diagram of closed loop system with motor load

Figure 17 shows the input supply of closed loop system connected with the motor load. Under this loaded condition the torque developed in the motor and the corresponding speed of the motor is shown in Figure 18 and Figure 19.

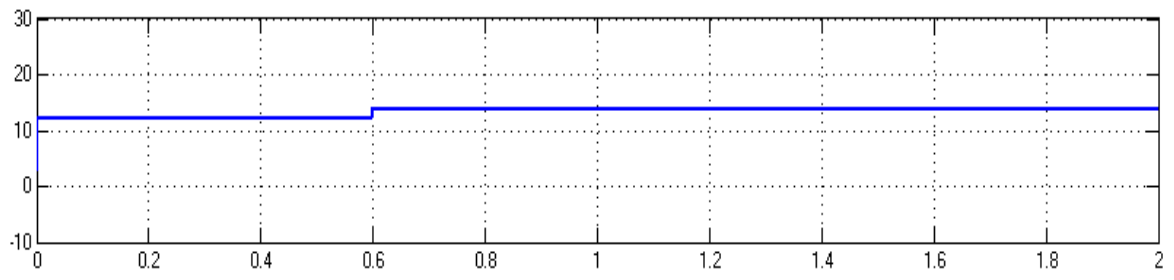

Figure 17. Input voltage

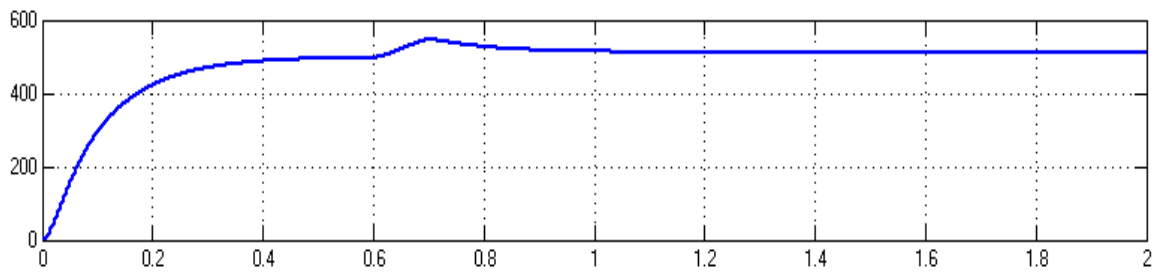

Figure 18. Motor speed

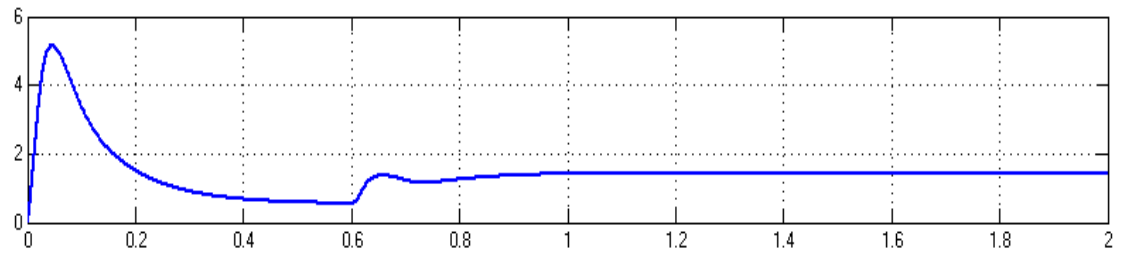

Figure 19. Motor torque 


\section{PROPOSED CLOSED LOOP SYSTEM WITH FUZZY LOGIC CONTROLLER}

The Figure 20 shows the fuzzy logic based automatic control system. Here the mandani method is used for fuzzification process and centroid method is used for defuzzification process so as to get the crisp output.

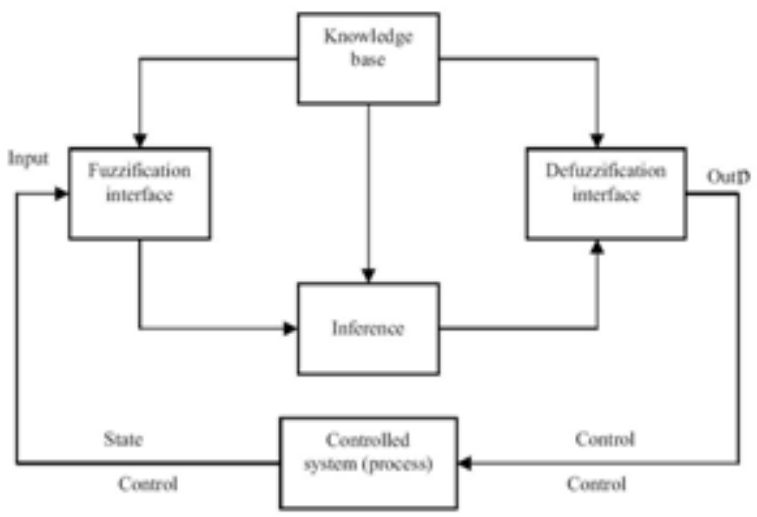

Figure 20. Fuzzy logic controller

\subsection{Simulink model for proposed converter using fuzzy logic controller with $\mathbf{R}$ load}

Figure 21 shows the simulation diagram of fuzzy logic based closed loop system with resistive load. The disturbance is created at the input terminal by giving the time response at $0.3 \mathrm{~ms}$ and the amplitude value is about $0.5 \mathrm{~V}$ both the time response and the amplitude values are not exact values.

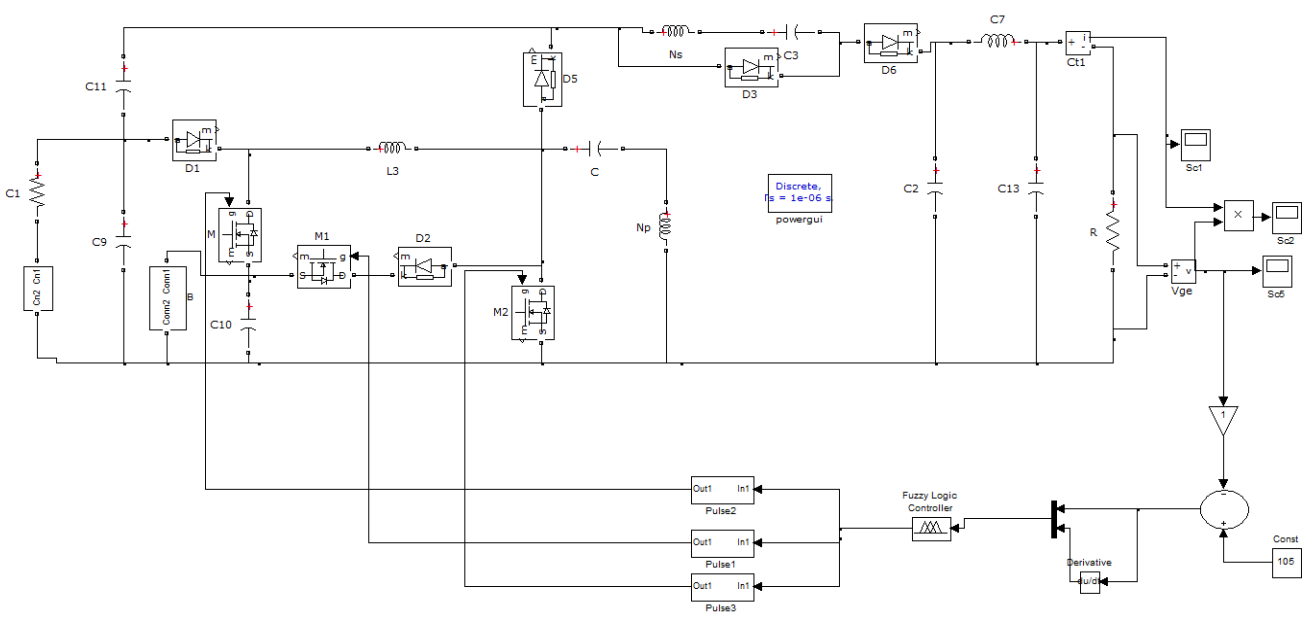

Figure 21. Simualtion diagram of fuzzy based closed loop system R load

The fuzzy logic controller which is used as closed loop controller will take the signal from the feedback element. The feedback element will take the signal from the load and it will compare the results with the reference valve. From that feedback signal the output will go through the derivative block where it will check run time error and give signals to the fuzzy logic controller. Here we are using centroid method rule based membership function. The fuzzy logic controller will act depending on the the time response that is given to the pulse generators. The changes due to disturbance can be reflected at 0.3 seconds in output voltage shown in Figure 22. The output can be maintained constant after 0.3 seconds. 


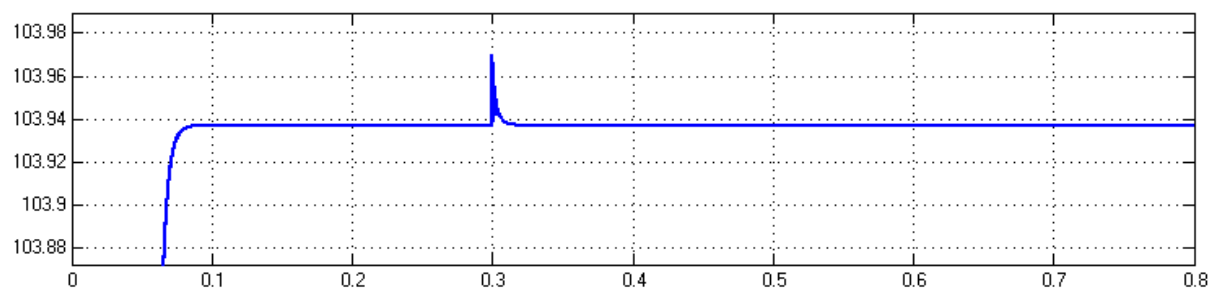

Figure 22. Output voltage

Figure 23 shows that ouput current across the resistive load of $1.1 \mathrm{~A}$. The output power is improved drastically and $1106 \mathrm{~W}$ is achieved. The output power yielded under the resistive loaded condition is shown in Figure 24.

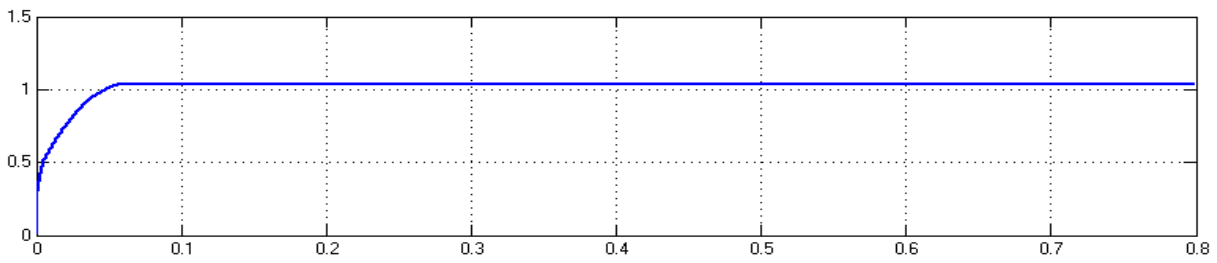

Figure 23. Output current

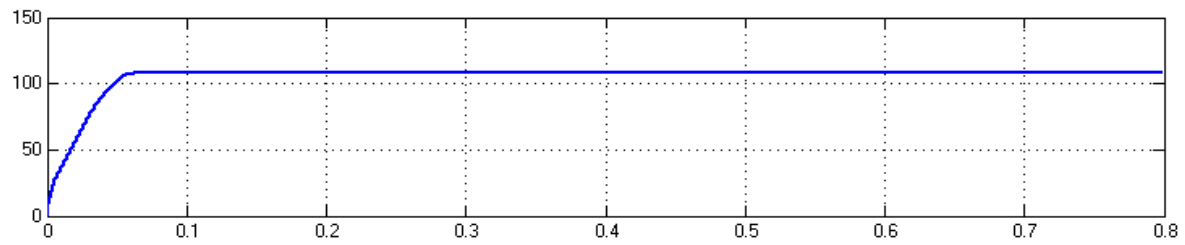

Figure 24. Output power

\subsection{Simulink model for proposed converter using fuzzy logic controller with motor load}

Figure 25 shows the simulation illustration of fuzzy logic controller based closed loop system with motor load. Depending on the output range from the fuzzy controller the pulses will be generated to the mosfet switches. According to this signals the mosfets will either on or off. The range for the switches are operated under180 degrees modes of operation.

The rotating speed of the motor is shown in Figue 26. The snubber protection is provided to diminish the voltage spikes. In this among all the three switches the second switch will act as regenerative snubber switch which will be used to reduce spike voltage near the switches [19]-[21].

Figure 27 shows the torque developed in the motor and settle down at $0.3 \mathrm{sec}$ as shown in. The below data is the difference between the PI and fuzzy logic controllers [22]-[25]. When compared to the PI and fuzzy logic controller output results beter performance in fuzzy logic control.

There is a large amount of decrease in both time domain specifications and error. So it is best to go for the fuzzy logic controller for closed loop purpose when compared to the other controllers. In the time response analysis of the fuzzy logic based converter the output ripple voltage isreduced from $0.25 \mathrm{~V}$ to 0.002 $\mathrm{V}$. Pi filter produces minimum ripple voltage. $\mathrm{T}_{\mathrm{r}}$ reduced from $0.33 \mathrm{~s}$ to $0.30 \mathrm{~s}$, $\mathrm{T}_{\mathrm{p}}$ reduced from $0.35 \mathrm{~s}$ to 0.31 $\mathrm{s}, \mathrm{T}{ }_{\mathrm{s}}$ reduced from $0.44 \mathrm{~s}$ to $0.32 \mathrm{~s}$ and the steadty state error is reduced from $1.2 \mathrm{~s}$ to $0.09 \mathrm{~s}$. 


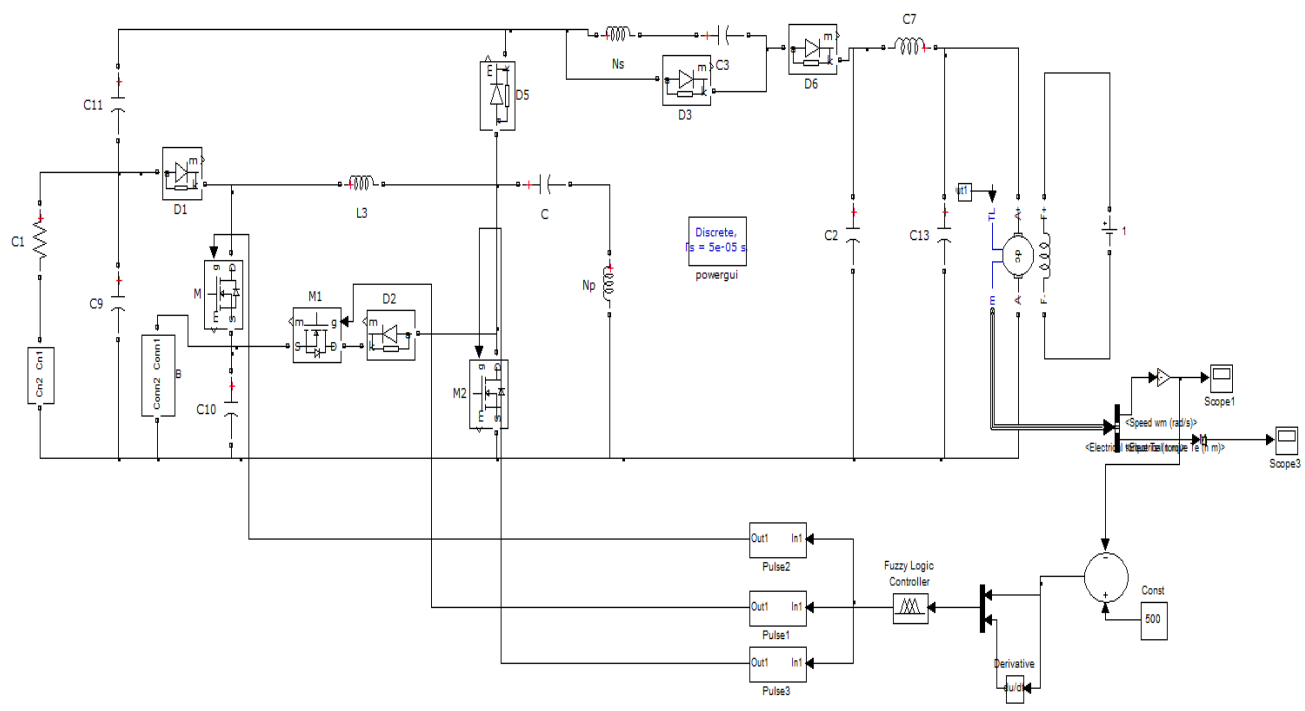

Figure 25. Simualtion diagram of fuzzy based closed loop system R load

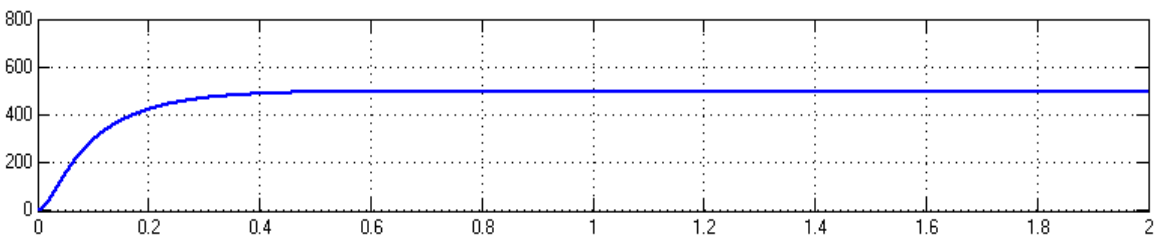

Figure 26. Motor speed

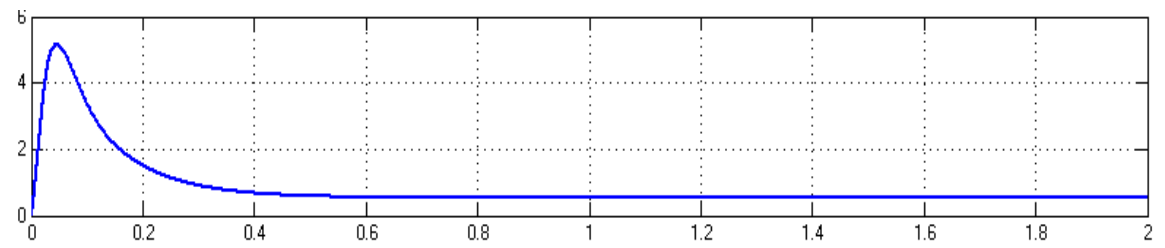

Figure 27. Motor torque

\section{CONCLUSION}

Overall, we can see that with the usage of the proposed non isolated three port fuzzy logic based converter various time domain parameters are enhanced while operation. Also in this paper we can see that fuzzy logic contoller gives better results when compared with pi controller compared with all the mechanical characteistics.In this multi port fuzzy based converter the number of switches are considerably reduced. The time response of this system also enhanced significantly.

\section{REFERENCES}

[1] A. I. Bratcu, I. Munteanu, S. Bacha, D. Picault, and B. Raison, "Cascaded dc-dc converter photovoltaic systems: power optimization issues," IEEE Trans. Ind. Electron., vol. 58, no. 2, pp. 403-411, Feb. 2011, doi: 10.1109/TIE.2010.2043041.

[2] M. Cacciato, A. Consoli, R. Attanasio, and F. Gennaro, "Soft-switching converter with HF transformer for gridconnected photovoltaic systems," IEEE Trans. Ind. Electron, vol. 57, no. 5, pp. 1678-1686, May 2010, doi: 10.1109/TIE.2009.2032201.

[3] H. Seong, H. Kim, K. Park, G. Moon and M. Youn, "High Step-Up DC-DC Converters Using Zero-Voltage Switching Boost Integration Technique and Light-Load Frequency Modulation Control," IEEE Transactions on Power Electronics, vol. 27, no. 3, pp. 1383-1400, Mar. 2012, doi: 10.1109/TPEL.2011.2162966. 
[4] F. Z. Peng, H. Li, G. J. Su, and J. S. Lawler, "A new ZVS bidirectional DC-DC converter for fuel cell and battery application," IEEE Trans. Power Electron., vol. 19, no. 1, pp. 54-65, Jan. 2004, doi: 10.1109/TPEL.2003.820550.

[5] Dhanya K Panicker, and Remya Mol, "Hybrid pi-fuzzy controller for brushless dc motor speed control," IOSR Journal of Electrical and Electronics Engineering (IOSR-JEEE), vol. 8, no. 6, pp. 33-43, Nov. 2013.

[6] K. Sun, L. Zhang, Y. Xing, and J. M. Guerrero, "A distributed control strategy based on dc bus signaling for modular photovoltaic generation systemwithbatteryenergystorage," IEEE Trans Power Electron., vol. 26, no. 10, pp. 3032-3045, Oct. 2011, doi: 10.1109/TPEL.2011.2127488.

[7] S. H. Hosseini, S. Danyali, and S. A. Nejabatkhah, "Modeling and control of a new three-input dc-dc boost converter for hybrid PV/FC/battery power system," IEEE Trans. Power Electron., vol. 27, no. 5, pp. 2309-2324, May 2012, doi: 10.1109/TPEL.2011.2172465.

[8] R. Samuel Rajesh Babu, "A Comparative Analysis of Integrated Boost Flyback Converter using PID and Fuzzy Controller," International Journal of Power Electronics and Drive System (IJPEDS), vol. 5, no. 4, pp. 486-501, Apr. 2015, doi: 10.11591/ijpeds.v5.i4.pp486-501.

[9] S. Assahout, H. Elaissaoui, A. El Ougli, B. Tidhaf, "Neural Network and Fuzzy Logic based MPPT Algorithm for Photovoltaic Pumping System," International Journal of Power Electronics and Drive System (IJPEDS), vol. 9, no. 4, pp. 1823-1833, Dec. 2018, doi: 10.11591/ijpeds.v9.i4.pp1823-1833.

[10] Y. Weng Kean, A. K. Ramasamy, S. Sukumar, M. Marsadek, "Adaptive Controllers for Enhancement of StandAlone Hybrid System Performance," International Journal of Power Electronics and Drive System (IJPEDS), vol. 9, no. 3, pp. 979-986, Sep. 2018, doi: 10.11591/ijpeds.v9.i3.pp979-986.

[11] D. Genesh, S. Moorthi, H. Sudheer, "A Voltage Controller in Photo-Voltaic System with BatteryStorage for StandAlone Applications," International Journal of Power Electronics and Drive System (IJPEDS), vol.2, no.1, pp. 9-18, Mar. 2012, doi: 10.11591/ijpeds.v2i1.127.

[12] D. Ramya, A. S. Mary Antony, "A reconfigurable five/seven level inverter with reduced switching losses," 2017 International Conference on Computation of Power, Energy Information and Commuincation (ICCPEIC), 2017, pp. 656-659, doi: 10.1109/ICCPEIC.2017.8290442.

[13] D. Ramya, et al., "Design of interleaved flyback converter," International Journal of Intelligent Enterprise, vol. 6, no. $1,2019$.

[14] Atri, K. Parag, P. S. Modi, and N. S. Gujar, "Comparison of Different MPPT Control Strategies for Solar Charge Controller," 2020 International Conference on Power Electronics\&IoT Applications in Renewable Energy, pp. 6569,2020

[15] Sahoo, Saroja Kanti, and Nudurupati Krishna Kishore, "Battery state-of-charge-based control and frequency regulation in the MMG system using fuzzy logic," IET Generation, Transmission \& Distribution, vol. 14, no. 14, pp. 2698-2709, 2020.

[16] A. Emad, Mohmed El-Shimy, Ghada Amer, and Ilham Ihoume, "Power Management Control of Hydrogen-Based System Using Fuzzy Logic Method," 2020 International Conference on Electrical and Information Technologies (ICEIT), 2020

[17] V. Meenakshi, F. Roseline, M. L. Bharathi, "Design of led street lighting using Arduino," Journal of Advanced Research in Dynamical and Control Systems, vol. 11, no. 4, pp. 18-22, Jan. 2019.

[18] K. R. Fathima, M. L. Bharathi, "A novel grid integration scheme for the hybrid electric power generation using solar and wind energy resources," 2017 International Conference on Computation of Power, Energy Information and Commuincation (ICCPEIC), Mar. 2017, doi: 10.1109/ICCPEIC.2017.8290434.

[19] M. L. Bharathi, D. Kirubakaran, "Neural Network Controlled High-Step Up Based Single-Phase PV Inverter System with Improved Dynamic Response," Journal of Computational and Theoretical Nanoscience, vol. 14, no. 1, pp. 421-429, Jan. 2017, doi: 10.1166/jctn.2017.6338.

[20] M. L. Bharathi, D. Kirubakaran, "Fuzzy logic-controlled PV supported triple stage ILBC converter system with improved dynamic response," 2017 International Conference on Computation of Power, Energy Information and Commuincation (ICCPEIC), 2017, pp. 592-598, doi: 10.1109/ICCPEIC.2017.8290433.

[21] R. F. Basha, M. L. Bharathi, "A Wind Energy Supported DSTATCOM for Real and Reactive Power Support for a Linear Three-Phase Industrial Load," International Conference on Intelligent Computing and Communication, pp. 755-767, Jun. 2019.

[22] D. Ramya, J. Sangeetha, A. S. Antony, "A Soft Switched Safety Enhanced Single Output Flyback Converter. Research Journal of Applied Sciences," Engineering and Technology, vol. 10, no. 6, pp. 688-693, 2015, doi: 10.19026/rjaset.10.2478.

[23] R. Ganapathi, D. Ramya, "High Power Density Parallel Resonant Inverter Using Bridgeless Boost Rectifier and Switched Capacitor Cell for Induction Heating," IOSR Journal of Electronics and Communication Engineering, 2017.

[24] J. Sangeetha, A. S. Antony, D. Ramya, "A Boosting Multi Flyback Converter for Electric Vehicle Application," Research Journal of Applied Sciences, Engineering and Technology, vol. 10, no. 10, pp. 1133-1140, Aug. 2015.

[25] M. Sangeetha, S. Prakash, D. Ramya, "Wear properties estimation and characterization of coated ceramics with multiwall carbon nano tubes (MWCNT) reinforced in aluminium matrix composites," Materials Today: Proceedings, vol. 3, no. 6, pp. 2537-2546, doi: 10.19026/rjaset.10.1881. 